\title{
Mexican American
}

National Cancer Institute

\section{Source}

National Cancer Institute. Mexican American. NCI Thesaurus. Code C67114.

Denotes an american citizen of Mexican descent. 